\title{
Mysterious Siberian crater attributed to methane
}

\section{Build-up and release of gas from thawing permafrost most probable explanation, says Russian team.}

\section{Katia Moskvitch}

31 July 2014

A mystery crater spotted in the frozen Yamal peninsula in Siberia earlier this month was probably caused by methane released as permafrost thawed, researchers in Russia say.

Air near the bottom of the crater contained unusually high concentrations of methane — up to $9.6 \%$ — in tests conducted at the site on 16 July, says Andrei Plekhanov, an archaeologist at the Scientific Centre of Arctic Studies in Salekhard, Russia.

Plekhanov, who led an expedition to the crater, says that air normally contains just $0.000179 \%$ methane.

Since the hole was spotted in mid-July by a helicopter pilot, conjecture has abounded about how the 30-metre-wide crater was formed - a gas or missile explosion, a meteorite impact and alien involvement have all been suggested.

But Plekhanov and his team believe that it is linked to the abnormally hot Yamal summers of 2012 and 2013, which were warmer than usual by an average of about $5^{\circ} \mathrm{C}$. As temperatures rose, the researchers suggest, permafrost thawed and collapsed, releasing methane that had been trapped in the icy ground.

Other researchers argue that long-term global warming might be to blame - and that a slow and steady thaw in the region could have been enough to free a burst of methane and create such a big crater. Over the past 20 years, permafrost at a depth of 20 metres has warmed by about $2^{\circ} \mathrm{C}$, driven by rising air temperatures ${ }^{1}$, notes Hans-Wolfgang Hubberten, a geochemist at the Alfred Wegener Institute in Potsdam, Germany.

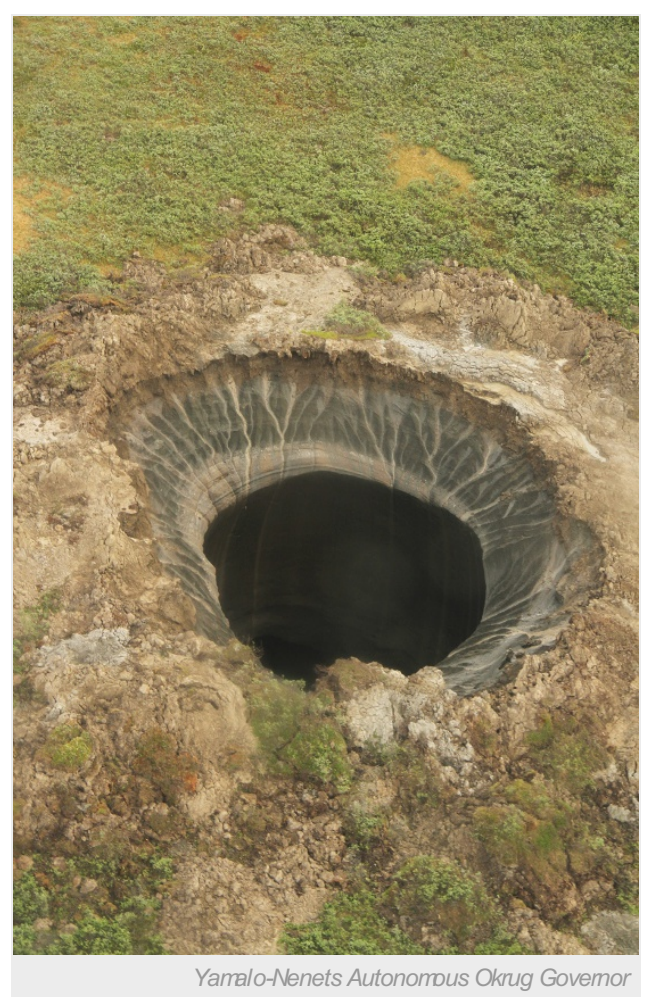

The crater in the Yamal peninsula in Siberia is 30metres wide.

Hubberten speculates that a thick layer of ice on top of the soil at the Yamal crater site trapped methane released by thawing permafrost. "Gas pressure increased until it was high enough to push away the overlying layers in a powerful injection, forming the crater," he says. Hubberten says that he has never before seen a crater similar to the Yamal crater in the Arctic.

Larry Hinzman, a permafrost hydrologist at the University of Alaska in Fairbanks and director of the International Arctic Research Center, says that such craters could become more common in permafrost areas as the region heats up.

In Siberian permafrost, large deposits of methane gas are trapped in ice, forming what is called a gas hydrate. Methane remains stable and frozen at certain temperatures, but as the permafrost warms, and its internal strength decreases, it may be less able to withhold the build-up of sub-surface gases, he says, leading to a release.

But such gas hydrates normally occur at depths of at least 100 metres, says Carolyn Ruppel, a geophysicist in charge of the gas hydrates project at the US Geological Survey in Woods Hole, Massachusetts. The depth of the Siberian crater is not known. When Plekhanov and his team tried to measure its depth with a video camera tied to a 50-metre rope, the camera did not reach the bottom. But the video footage suggests that the depth to a pool of water at the bottom of the crater is around 70 metres, Plekhanov says. The water could add considerably to that dry depth, he adds.

To confirm what caused the crater, Plekhanov says that another visit is needed to check the methane concentration in air trapped in its walls. That will be difficult, however: "Its rims are slowly melting and falling into the crater," Plekhanov says. "You can hear the ground falling, you can hear the water running, it's rather spooky." 
Since the crater was reported, local reindeer herders have noted a similar but smaller hole nearby. Although the hole is yet to be confirmed, scientists worry that the release of trapped methane could threaten local industry and communities. "If [a release] happens at the Bovanenkovskoye gas field that is only $30 \mathrm{~km}$ away, it could lead to an accident, and the same if it happens in a village," says Plekhanov.

To avoid such an event, the Russian team has now suggested drilling holes into the permafrost to release the pressure artificially. But Hinzman says that it would be extremely difficult to do so, if not impossible, as one would have to know exactly where the build-up was in the first place.

Nature I doi:10.1038/nature.2014.15649

\section{References}

1. Romanovsky, V. E., Smith, S. L. \& Christiansen, H. H. Permafrost Periglac. 21, 106-116 (2010). 